\title{
Artifactual effects of caging on the recruitment and survivorship of a subtidal colonial invertebrate
}

\author{
Laura J. Stocker*
}

Zoology Department and Leigh Marine Laboratory, University of Auckland, Auckland, New Zealand

\begin{abstract}
As an aid to interpreting previous experiments and designing future experiments, I tested the hypothesis that the presence of cages has the same effect as the absence of invertebrate grazers on the recruitment of a subtidal colonial ascidian at Goat Island, New Zealand. Recruitment of the ascidian Pseudodistoma novaezelandiae (Brewin) (Polyclinidae: Euherdmaniinae) under cages was compared to recruitment in uncaged quadrats, while both treatments were manually kept clear of 2 invertebrate grazers, the echinoid Evechinus chloroticus (Val.) and the large gastropod Cookia sulcata (Gmelin). Thus, any effect of the cages could not be due to the absence of grazers and was considered artifactual. Although the effect of caging was initially non-significant, in later samples there were significantly more recruits outside thañ inside câges. Sügg̣ested causes of the caỵiñy effect include the activities of blennies which sheltered within cages, and the increase of sediment within cages.
\end{abstract}

Cages have been widely used in benthic field experiments to exclude predators, but increasing evidence suggests that cages have effects on their interior environment other than the simple exclusion of predators (Dayton \& Oliver 1980, Hulberg \& Oliver 1980, Kennelly 1983, Schmidt \& Warner 1984, Underwood \& Denley 1984). One method of assessing the importance of these artifactual effects is by the use of partial cages which ideally are meant to simulate the regime created by the full cage in all respects except for the exclusion of predators (Russ 1980, Breitberg 1985). These 'caging controls', however, may themselves produce unpredictable or, worse, undetected effects (Dayton \& Oliver 1980, Choat 1982, Keough 1984) such as the alteration of behaviour patterns of surrounding animals, which in turn produces artifacts (Otsuka \& Dauer 1980, Keough 1984). An alternative method of isolating artifacts produced by cages from the effects of predation involves the deployment of cages in the absence of predators

\footnotetext{
- Present address: Zoology Building, School of Biological Sciences, University of Sydney, NSW 2006, Australia
}

(Kennelly 1983). Any difference between the caged and uncaged treatments cannot be due to the hypothesised predators and can be considered artifactual. Such a test for the effects of cages per se is made in tandem with a test for the effects of predators.

The work described here was part of a larger study (Stocker \& Bergquist unpubl.) on factors affecting recruitment of the ascidian Pseudodistoma novaezelandiae (Brewin). As cages had proved convenient in previous studies, they would be a desirable method of excluding grazers in future experiments, if their artificial effects could be shown to be small. In the present study, the possibility of artifactual effects of cages on recruitment was investigated by establishing caged and uncaged treatments in areas from which 2 hypothesised agents of mortality, the urchin Evechinus chloroticus and the large grazing gastropod Cookia sulcata, had been manually removed. These grazers occur at high densities and the echinoids are known to be omnivorous (Ayling 1981). The experiment, it should be stressed, was not an attempt to distinguish preferential settlement from post-settlement mortality, but to measure the effects of cages, other than the exclusion of invertebrate grazers, on recruitment. In this paper, I use the term 'settlement' to mean the attachment of larvae to the substratum and their metamorphosis, and 'recruitment' to refer to settlers that have survived long enough to be observed (Keough \& Downes 1982).

Materials and methods. The study was made at inner North Reef on the north-western point of Goat Island in the Leigh Marine Reserve, north-east New Zealand $\left(36^{\circ} 15^{\prime} \mathrm{S} ; 174^{\circ} 48^{\prime} \mathrm{E}\right)$. The site is 5 to $8 \mathrm{~m}$ deep and is characterised by numerous boulders 1 to $3 \mathrm{~m}$ in diameter. The boulders are largely covered with a mixture of turfing and encrusting coralline algae, and the barnacle Balanus trigonus Darwin. Pseudodistoma novae- 


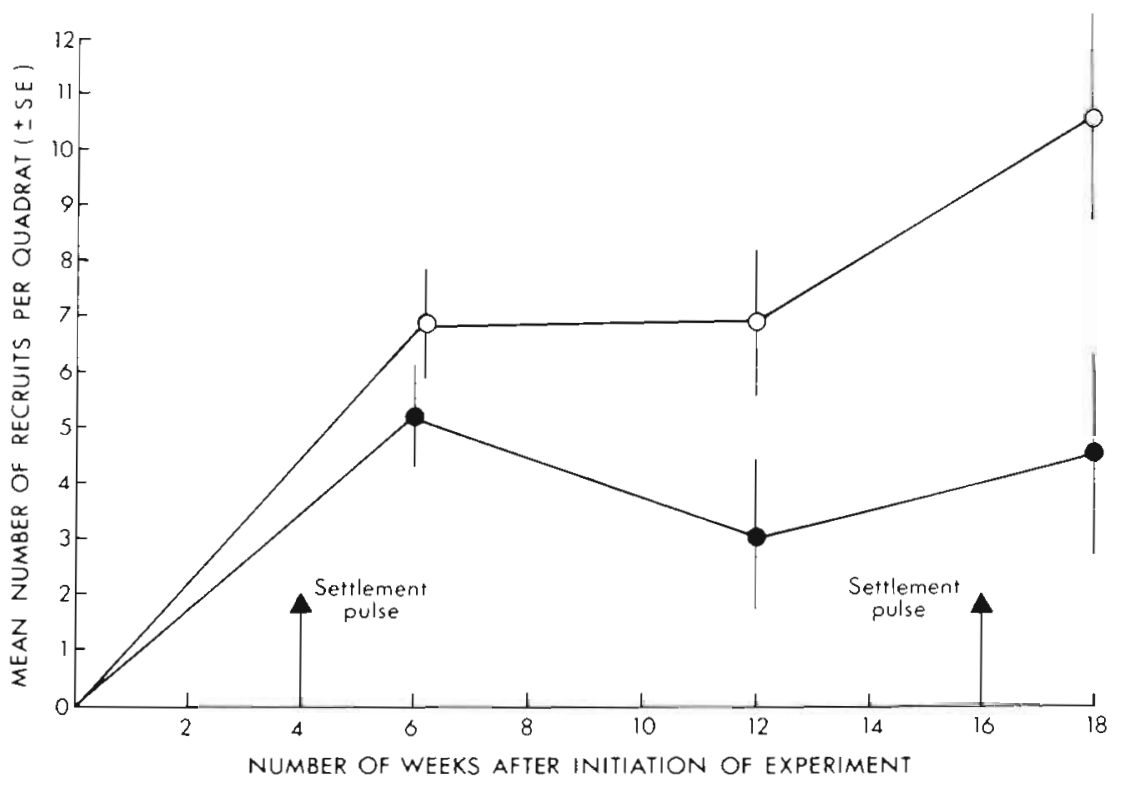

Fig. 1. Mean number of recruits per quadrat ( $\pm \mathrm{SE}_{i} \mathrm{n}=20$ ). (O) Uncaged quadrats; $(\bullet$ ) caged quadrats. Periods of intense settlement are marked 'settlement pulse' zelandiae occupied a mean of $9.1 \%(\mathrm{SE}=5.6 ; \mathrm{n}=20)$ of the available space on boulders. The colonies are vivid orange and gelatinous, in the form of lobes growing up from a basal mat. The echinoid Evechinus chloroticus and the gastropod Cookia sulcata occurred at mean densities of $8.8 \mathrm{~m}^{-2}(\mathrm{SE}=1.2 ; \mathrm{n}=25)$ and $3.2 \mathrm{~m}^{-2}(\mathrm{SE}=0.8 ; \mathrm{n}=20)$, respectively.

A 2 -factor design was used to determine the variability among boulders in the recruitment of Pseudodistoma novaezelandiae and the effects of caging on recruitment. Recruitment was measured within quadrats marked out on the natural substratum of turfing corallines and barnacles; these quadrats did not contain $P$. novaezelandiae colonies. Eight quadrats were established on the tops of each of 5 randomly-selected boulders bearing $P$. novaezelandiae. Cages were then assigned randomly to 4 quadrats, and 4 quadrats were left uncaged. Thus, the factor 'Boulders' was random with 5 levels and was orthogonal with the factor 'Caging' which was fixed with 2 levels.

The cages were of plastic mesh $2 \mathrm{~mm}$ thick with a grid size of $2 \times 2 \mathrm{~cm}$, covered an area of $25 \times 25 \mathrm{~cm}$, and were $6 \mathrm{~cm}$ high. Skirting edges of the cages were nailed to the substratum under strips of plastic to prevent the entry of grazers. Invertebrate grazers were removed from all boulders approximately twice a week. The sides of the boulders acted as buffer zones across which grazers could rarely proceed, so the boulder-tops remained free of invertebrate grazers. Numbers of recruits in the quadrats were recorded at 6,12 , and $18 \mathrm{wk}$ after the experiment was started.

Numbers of the blenny Parablennius laticlavius Griffin on caged and uncaged quadrats were counted, and light intensity on caged and uncaged quadrats was measured with a Licor Quantum Photometer/ Radiometer.

Results and Discussion. The experiment had been established for $4 \mathrm{wk}$ when recruitment of Pseudodistoma novaezelandiae was first observed, but a large swell prevented immediate sampling. At the first sampling, $6 \mathrm{wk}$ after the experiment was established, there was no significant effect from Caging (Table 1a, Fig. 1). Thus, although cages caused a $27 \%$ decrease in light intensity relative to uncaged quadrats (mean light intensity inside cages was $438 \mu \mathrm{E} \mathrm{s}^{-1} \mathrm{~cm}^{-2}$; $\mathrm{SE}=$ 10.5: $\mathrm{n}=5$, and outside cages was $596 \mu \mathrm{E} \mathrm{s}^{-1} \mathrm{~cm}^{-2}$;

Table 1. Analysis of variance tables for number of recruits at (a) $6 \mathrm{wk}$ (b) $12 \mathrm{wk}$ and (c) $18 \mathrm{wk}$ after initiation of experiment. Data were $\ln (x+1)$ transformed for (b) and (c) to homogenise variances. $\cdots p<0.005$

\begin{tabular}{|c|c|c|c|c|c|c|c|}
\hline \multirow{2}{*}{$\begin{array}{c}\text { Source of } \\
\text { variation }\end{array}$} & \multirow[t]{2}{*}{ df for $F$} & \multicolumn{2}{|c|}{ (a) $6 \mathrm{wk}$} & \multicolumn{2}{|c|}{ (b) $12 \mathrm{wk}$} & \multicolumn{2}{|c|}{ (c) $18 \mathrm{wk}$} \\
\hline & & MS & F & MS & F & MS & $\mathrm{F}$ \\
\hline Caging & 1,4 & 28.9 & 2.80 & 4.75 & $23.75^{\cdots}$ & 8.46 & $33.16^{\circ}$ \\
\hline Boulders & 4,4 & 59.81 & 1.83 & 1.23 & 1.49 & 1.71 & 1.96 \\
\hline $\mathrm{Ca} . \times \mathrm{B}$ & 4,30 & 10.34 & 0.32 & 0.2 & 0.24 & 0.26 & 0.28 \\
\hline Residual & 30 & 32.62 & & 0.83 & & 0.88 & \\
\hline Total & 39 & & & & & & \\
\hline
\end{tabular}


$\mathrm{SE}=5.5 ; \mathrm{n}=5$ ), it appears that the difference in light regimes between the 2 treatments did not cause differential settlement.

Between 6 and 12 wk there was very little new recruitment, but by $12 \mathrm{wk}$ there had developed a significant Caging effect (Table 1b, Fig. 1), presumably as a result of differential survivorship of old recruits. At ca $16 \mathrm{wk}$ there was another settlement pulse. Two wk after this, the experiment was sampled for the third time and the Caging effect was again significant (Table $1 \mathrm{c}$ ). Mortality of recruits may have resulted from the increased sediment observed inside the cages. In addition, predation or dislodgment of settlers by blennies sheltering inside the cages may have been important. At the end of the experiment, blennies occurred at a mean density of $0.68(\mathrm{SE}=0.05 ; \mathrm{n}=80)$ per caged quadrat, whereas a total of only one blenny was found on all the uncaged quadrats. These blennies are known to eat newly settled larvae of encrusting invertebrates (Ayling \& Cox 1982). The occurrence of fewer recruits on caged than uncaged quadrats confirmed initial field observations that predation by large benthic-feeding fish was not an important factor in Pseudodistoma novaezelandiae recruitment.

At no time was there significant variability in recruitment among boulders, nor was there any interaction between Boulders and Caging (Table 1).

Results from this study confirmed the findings of previous workers (Marshall et al. 1980, Russ 1980, Otsuka \& Dauer 1982, Schmidt \& Warner 1984) who showed that the presence of exciusion cayes may not be equivalent to the absence of hypothesised predators in their effects on the treated biota.

It was concluded that despite the greater effort required, manual removal of grazers is a more desirable option than caging in experiments on recruitment of Pseudodistoma novaezelandiae (Stocker \& Bergquist unpubl.), and possibly of other encrusting invertebrates as well. It is not always possible to continue manual removal of predators but small-scale investigations of this kind should be an option for pilot studies or as an adjunct to main experiments. If caging were shown to have no effect it could be used, with more confidence, in subsequent studies. On the other hand, if the direction and magnitude of effects of the cages themselves are measurable from a pilot or ancillary study, then assuming additivity, effects of predation could be deduced by subtraction from the total effect of caging plus predation, in future experiments.
Acknowledgements. I thank N. L. Andrew, B. D. Mapstone, A. J. Underwood and 3 anonymous referees for useful comments on the manuscript; and P. R. Bergquist, M. J. Kingsford, and A. B. MacDiarmid for criticising early drafts. Staff and colleagues at the Leigh Marine Laboratory are gratefully acknowledged for their assistance.

\section{LITERATURE CITED}

Ayling, A. M. (1981). The role of biological disturbance in temperate, subtidal encrusting communities. Ecology 62 : 830-847

Ayling, A. M., Cox, G. J. (1982). Collins guide to the sea fishes of New Zealand. Collins, Auckland

Breitburg, D. L. (1985). Development of a subtidal epibenthic community: factors affecting species composition and the mechanisms of succession. Oecologia (Berl.) 65: 173-184

Choat, J. H. (1982). Fish feeding and the structure of benthic communities in temperate waters. Ann. Rev. Ecol. Syst. 13: $423-449$

Dayton, P. K., Oliver, J. S. (1980). An evaluation of experimental analyses of population and community patterns in benthic marine environments. In: Tenore, K. R., Coull, B. C. (ed.) Marine benthic dynamics. Univ. of South Carolina Press, Columbia, p. 93-120

Hulberg, L. W., Oliver, J. S. (1980). Caging manipulations in marine soft-bottom communities: importance of animal interactions or sedimentary habitat modifications. Can. J. Fish. Aquat. Sci. 37: 1130-1139

Kennelly, S. J. (1983). An experimental approach to the studies of factors affecting algal colonisation in a sublittoral kelp forest. J. exp. mar. Biol. Ecol. 68: 257-276

Keough, M. J. (1984). Dynamics of the epifauna of the bivalve Pinna bicolor: Interactions among recruitment, predation. and competition. Ecology 65: 677-688

Keough, M. J., Downes, B. J. (1982). Recruitment of marine invertebrates: the role of active larval choices and early mortality. Oecologia (Berl.) 54: 348-352

Marshall, J. J., Rowe, F. W. E., Fisher, R. P., Smith, D. F. (1980). Alterations to the relative species-abundance of ascidians and barnacles in a fouling community due to screens. Aust. J. mar Freshwat. Res. 31: 147-153

Otsuka, C. M., Dauer, D. M. (1982). Fouling community dynamics in Lynnhaven Bay, Virginia. Estuaries 5: 10-22

Russ, G. R. (1980). Effects of predation by fishes, competition, and structural complexity of the substratum on the establishment of a marine epifaunal community. J. exp. mar. Biol. Ecol. 42: 55-69

Schmidt, G. H., Warner, G. F. (1984). Effects of caging on the development of a sessile epifaunal community. Mar. Ecol. Prog. Ser. 15: 251-263

Underwood, A. J., Denley, E. J. (1984). Paradigms, explanations, and generalizations in models for the structure of intertidal communities on rocky shores. In: Strong, D. R., Simberloff, D., Abele, L. G., Thistle, A. B. (ed.) Ecological communities: conceptual issues and the evidence. Princeton University Press, Princeton, p. 151-180

Accepted for printing on October 3, 1986 